\title{
RELIABILITY PAPER Prioritisation of root cause analysis in production disturbance management
}

\author{
Adriana Soares Ito and Torbjörn Ylipää \\ Chalmers University of Technology, Gothenburg, Sweden \\ Per Gullander \\ RISE Research Institutes of Sweden AB, Mölndal, Sweden, and \\ Jon Bokrantz and Anders Skoogh \\ Chalmers University of Technology, Gothenburg, Sweden
}

\begin{abstract}
Purpose - Manufacturing companies struggle to manage production disturbances. One step of such management deals with prioritising those disturbances which should undergo root cause analysis. The focus of this work is on two areas. First, investigating current challenges faced by manufacturing companies when prioritising root cause analysis of production disturbances. Second, identifying the stakeholders and factors impacted by production disturbances. Understanding the current challenges and identifying impacted stakeholders and factors allows the development of more efficient prioritisation strategies and, thus, contributes to the reduction of frequency and impact of disturbances.

Design/methodology/approach - To achieve the intended purpose of this research, a qualitative approach was chosen. A series of interviews was conducted with practitioners, to identify current challenges. A series of focus groups was also held, to identify the impacted stakeholders and factors by disturbances.

Findings - Various challenges were identified. These are faced by manufacturing companies in their prioritisation of production disturbances and relate to the time needed, criteria used, centralisation of the process, perspective considered and data support. It was also found that a wide range of stakeholders is impacted by production disturbances, surpassing the limits of production and maintenance departments. Furthermore, the most critical factors impacted are quality, work environment, safety, time, company results, customer satisfaction, productivity, deliverability, resource utilisation, profit, process flow, plannability, machine health and reputation.

Originality/value - The current situation regarding root cause analysis prioritisation has not been identified in previous works. Moreover, there has been no prior systematic identification of the various stakeholders and factors impacted by production disturbances.
\end{abstract}

Keywords Production disturbances, Prioritisation, Root cause analysis, Stakeholders

Paper type Research paper

(C) Adriana Soares Ito, Torbjörn Ylipää, Per Gullander, Jon Bokrantz and Anders Skoogh. Published by Emerald Publishing Limited. This article is published under the Creative Commons Attribution (CC BY 4.0) licence. Anyone may reproduce, distribute, translate and create derivative works of this article (for both commercial and non-commercial purposes), subject to full attribution to the original publication and authors. The full terms of this licence may be seen at http://creativecommons.org/licences/by/4.0/ legalcode

This work has been conducted under the Sustainable Production Initiative and Production Area of Advance at Chalmers. There is no potential conflict of interest in this research. The project was financed by VINNOVA, Energimyndigheten and Formas, in the Produktion2030 programme. The authors are thankful to the research team in the "D3H" project for their work. The support of all these bodies is greatly appreciated.

Production

disturbance prioritisation

Received 9 December 2020 Revised 27 April 2021 Accepted 10 May 2021 
IJQRM

39,5

\section{Introduction}

Digitalisation is changing how companies manage their production systems. However, reducing the occurrence of production disturbances remains one of the main goals of a production manager. Manufacturing companies lose almost half their production capacity to disturbances (Ylipää et al., 2017). Therefore, companies may improve their business performance by reducing the frequency and duration of disturbances (Alsyouf, 2007; Ingemansson, 2004). For manufacturing companies to sustain and increase their competitiveness the efficient and effective management of production disturbances is required.

The management of production disturbances involves various stages, including detection, correction/mitigation, root cause analysis (RCA), prediction and risk evaluation. At all stages, a prioritisation strategy is often necessary due to the high number and great diversity of disturbances the system may encounter. Different prioritisation approaches may be used at each stage. As an example, failure modes and effects analysis (FMEA) is commonly applied to risk evaluation (Puente et al., 2002). Additionally, ABC analysis is prevalent when prioritising the correction of maintenance-related disturbances (Chong et al., 2019). On the stage of RCA, companies tend to use Pareto analysis to determine which disturbances should be investigated (Knights, 2001; Murugaiah et al., 2010). However, there are some drawbacks to the process, such as the prioritisation criteria used. Investigating how disturbances may be better prioritised at RCA stage is the focus of this study.

$\mathrm{RCA}$ is a structured investigation which aims to find the most basic reasons for a disturbance, the root causes (Mahto and Kumar, 2008). It also identifies the necessary countermeasures for eradicating root causes (Andersen and Fagerhaug, 2002). The recurrence of disturbances may only be avoided once the root causes have been eliminated (Mahto and Kumar, 2008). Thus, RCA is an essential step in developing a more resilient production system.

Even so, for various reasons, most manufacturing companies find it practically impossible to analyse all their production disturbances. First, the frequency of production disturbances may be very high (Islam and Tedford, 2012), perhaps hundreds a day. Second, the root cause analysis process tends to be time-consuming, sometimes taking months to complete (Andersen and Fagerhaug, 2002). Finally, resources for the analysis processes are frequently subject to budgetary constraints (Andersen and Fagerhaug, 2002). Thus, an efficient prioritisation strategy is needed, to determine which disturbances should undergo the RCA process.

Even though the RCA prioritisation of production disturbances is a practical problem faced by manufacturing companies, there is a scarcity of research that focuses on this phenomenon. To fill this research gap, this work aims to investigate the RCA prioritisation of disturbances, contributing to their reduction and creating more resilient production systems. Two steps are necessary to develop an effective prioritisation strategy. First, understanding the current situation and challenges faced by manufacturing companies in their RCA prioritisation process. Second, mapping the various stakeholders and factors impacted by production disturbances. Therefore, two research questions guide this study:

$R Q 1$. What are the current challenges faced by manufacturing companies when it comes to RCA prioritisation of production disturbances?

RQ2. What stakeholders and factors are impacted by the occurrence of production disturbances?

To answer the RQs, the authors conducted a series of interviews and focus groups. The interviews were held with practitioners from four different companies, while the focus groups involved both academics and practitioners. 
This paper is laid out as follows. First, the authors present the frame of reference to relate this work to previous publications, followed by a description of the methods used. Second, the results of the interviews and focus groups are presented, relating to the challenges, impacted stakeholders and factors. Third, a discussion is presented, with the implications of this work and proposals for future research. Finally, the conclusions are presented.

\section{Background}

\subsection{Root cause analysis of production disturbances}

Production disturbances are unexpected and undesired events that cause a production system to not perform as planned (Islam and Tedford, 2012; Stricker and Lanza, 2014). Bokrantz et al. (2016) pinpointed that the factors most often deemed production disturbances include equipment/software/media failure, human error, waiting time for materials, subsequent stops in output flow from stations/machines, shortage of staff, speed loss, scrap or quality problems, planning error and adjustments.

Disturbances are very common in the day-to-day operations of manufacturing companies (Islam and Tedford, 2012). This is reflected in the low overall equipment efficiency (OEE) numbers reported, confirming that manufacturing companies are struggling to use their production capacities effectively (Ylipää et al., 2017). Managing production disturbances properly is fundamental so that manufacturing companies can meet their business objectives (Islam and Tedford, 2012).

However, disturbance management actions tend to be more reactive-orientated. Once a disturbance happens, efforts are made to mitigate and correct it, ensuring that normal conditions are re-established (Leitao and Francisco, 2004). Nevertheless, to avoid a disturbance recurring, it is also necessary to analyse its root causes. This is an important step in gaining a comprehensive understanding of "what happened" and "why it happened"; rather like a detective solving a crime. RCA supports disturbance management so that companies become more proactive and not just reactive.

The RCA process usually involves the participation of a group, commonly of three to six people (Mahto and Kumar, 2008). Various tools and techniques may be used during the analysis, such as fault tree analysis, five whys and cause-and-effect diagrams (Abellana, 2020; Andersen and Fagerhaug, 2002; Dorsch et al., 1997; Mahto and Kumar, 2008; Reid and Smyth-Renshaw, 2012). The process usually involves problem understanding, data collection, data analysis, root causes identification and root causes elimination (Andersen and Fagerhaug, 2002). To make sure a specific disturbance will not recur, its root causes should be eradicated.

Nevertheless, for most companies, finding the root causes of all production disturbances is practically impossible. On the one hand, the RCA process demands time, effort and resources (Andersen and Fagerhaug, 2002) and, on the other, the frequency of disturbances in manufacturing companies is high. A prioritisation strategy is needed, to target those disturbances which, once eradicated, will provide the greatest value to the production system.

\subsection{Prioritisation and production disturbances}

According to Westbrook (1994), prioritisation concerns the allocation of resources, or expression of preference, in response to current pressures. The objective is to relieve those pressures whilst promoting the achievement of the company's strategic goals. Prioritising means determining what is most important and urgent and then emphasising that.

Once priorities are set, companies may increase the alignment and focus of groups, ensuring that resources are allocated to the right activities (Nieto-Rodriguez, 2016). Nevertheless, prioritising is not a simple task. Managers are typically pushed by many 
IJQRM

39,5

competing demands whilst having to contend with limited resources. Additionally, priorities are frequently set based on the subjective judgement of managers and the immediate needs of the situation (Chong et al., 2019; Watkins and Bazerman, 2003).

Various strategies are used to prioritise production disturbances. For example, at the risk analysis stage, FMEA is a commonly applied thinking-forward method (Andersen and Fagerhaug, 2002). In FMEA, potential failures are prioritised by calculating the risk priority number. This is the product of the risk factors of severity, occurrence and detection (Liu et al., 2013; Sankar and Prabhu, 2006). Criticisms of this method include the argument that risk factors are difficult to evaluate precisely and that the method is primarily applied in terms of safety (Liu et al., 2013).

At the stage of correcting production disturbances, $\mathrm{ABC}$ analysis is applied to prioritisation, especially for maintenance-related disturbances (Gopalakrishnan and Skoogh, 2018). In this case, the machines in production systems are classified and prioritised according to their function and impact on productivity. Disturbances in critical machines get a higher ranking in the $\mathrm{ABC}$ prioritisation.

RCA prioritisation still lacks an effective strategy. Manufacturing companies mainly prioritise their production disturbances by using Pareto graphs (Knights, 2001; Ylipää, 2000). Usually, the criteria examine production losses or OEE dimensions of availability, performance and quality. One criticism of this method is that, generally, it is not useful for trending comparisons (Knights, 2001). Moreover, this type of prioritisation tends to consider only the production or maintenance perspectives, without taking into account the fact that production disturbances also impact other functions.

\subsection{Stakeholders and factors}

To prioritise RCA of production disturbances effectively, it is necessary to recognise which ones are affected and how they are affected. In other words, when setting priorities, managers should be aware of the various stakeholders and factors that are impacted by disturbances.

Stakeholders are the individuals, groups and organisations affected by, or perhaps affecting, a phenomenon (Reed et al., 2009). This also includes non-humans and non-living entities. In business management, there has been a growing realisation that stakeholders may affect the success of an organisation (Reed et al., 2009). Stakeholder management is positively associated with shareholder value creation (Hillman and Keim, 2001).

Reed et al. (2009) claim that the literature dedicated to stakeholder theory has presumed stakeholders to be self-evident. Furthermore, the same authors claim that this literature has concentrated on categorising pre-identified stakeholders so as to comprehend their interests. However, before this can be done, it is essential to identify who holds a stake in the phenomenon under investigation (Reed et al., 2009). In the case of production disturbances, there has been no systematic identification of impacted stakeholders and factors.

\section{Research methods}

To increase the replicability of the research, the authors followed the recommendations for transparency in qualitative research proposed by Aguines and Solarino (2019). Therefore, in this section, the qualitative methods used, the research settings, the sampling procedures, the data collection and analysis are presented.

The research questions that guide this work are explorative in nature, focussing on better understanding the phenomenon of RCA prioritisation of production disturbances. Qualitative studies are suitable for investigating phenomena in cases where theory is still limited (Edmondson and Mcmanus, 2007), which is the case for this work. Figure 1 presents the research process, as guided by the research questions. The qualitative study was based on a series of interviews and focus groups. 


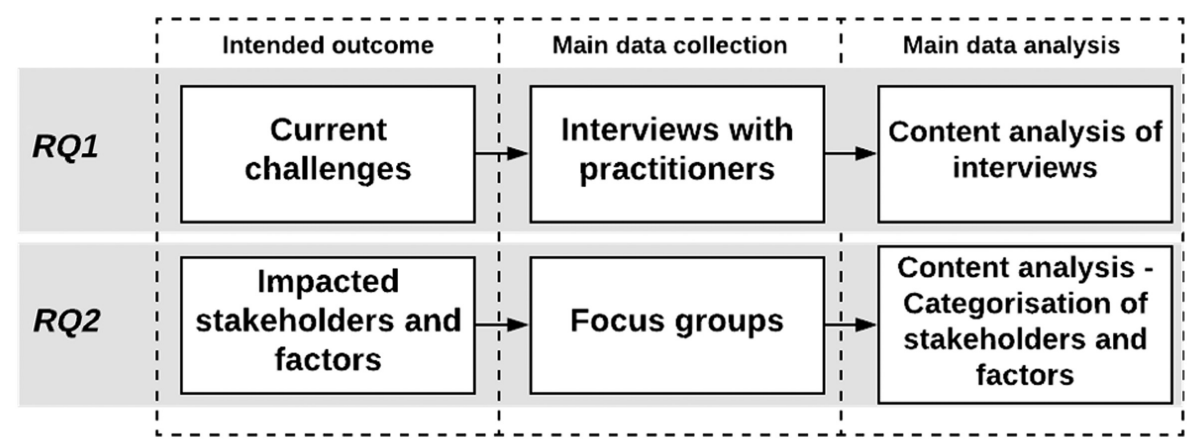

Production
disturbance
prioritisation

1137

Figure 1.

Research process

To map the current situation and challenges, the authors conducted a series of interviews with practitioners at four different manufacturing companies. For the selection of the companies, the authors looked for those that control their disturbances and keep records of events, with different industrial backgrounds. Four companies took part in this study, as shown in Table 1. In selecting interviewees, the authors focused on practitioners at those manufacturing companies who were working in production disturbance management (see Table 1).

Conducting interviews allowed us to explore the phenomenon in its natural setting. Using this method, knowledge may be constructed with a focus on actual practice (Voss et al., 2002). The authors chose to conduct semi-structured interviews since this allowed room for clarification of ambiguous responses and follow-up questions, in case of emergence of interesting data (Stokes and Bergin, 2006).

For the interviews, the authors followed an interview guide as suggested by Kallio et al. (2016) which they created and discussed in advance. In the interviews, the respondents were asked about the management process for production disturbances in general and the specific RCA prioritisation process. The focus was on the people

\begin{tabular}{|c|c|c|c|c|c|}
\hline Company & Industry type & $\begin{array}{l}\text { Type of } \\
\text { layout }\end{array}$ & $\begin{array}{l}\text { Number of } \\
\text { employees }\end{array}$ & $\begin{array}{l}\text { Number of } \\
\text { people } \\
\text { interviewed }\end{array}$ & Positions in company \\
\hline A & $\begin{array}{l}\text { Tool steel } \\
\text { manufacturer }\end{array}$ & $\begin{array}{l}\text { Job shop } \\
\text { production }\end{array}$ & 900 & 2 & $\begin{array}{l}\text { Technical engineer, } \\
\text { maintenance } \\
\text { supervisor }\end{array}$ \\
\hline B & $\begin{array}{l}\text { Cider and beer } \\
\text { brewery }\end{array}$ & $\begin{array}{l}\text { Process } \\
\text { batch-based }\end{array}$ & 460 & 3 & $\begin{array}{l}\text { Production manager, } \\
\text { maintenance manager, } \\
\text { continuous } \\
\text { improvement } \\
\text { coordinator }\end{array}$ \\
\hline $\mathrm{C}$ & $\begin{array}{l}\text { Manufacturer of steel } \\
\text { bar for building } \\
\text { structures }\end{array}$ & $\begin{array}{l}\text { Job shop } \\
\text { production }\end{array}$ & 25 & 2 & $\begin{array}{l}\text { Production manager, } \\
\text { production coordinator }\end{array}$ \\
\hline $\mathrm{D}$ & $\begin{array}{l}\text { Polymer component } \\
\text { manufacturer } \\
\text { focussing on } \\
\text { automotive industry }\end{array}$ & $\begin{array}{l}\text { Job shop } \\
\text { production }\end{array}$ & 114 & 3 & $\begin{array}{l}\text { Production manager, } \\
\text { consultant, continuous } \\
\text { improvement } \\
\text { coordinator }\end{array}$ \\
\hline
\end{tabular}

Table 1. Companies and interviewees 
IJQRM

39,5

involved, the criteria used, the frequency of meetings and the perception of their performance and challenges.

At least two of the authors took part in each of the interviews. All interviews were recorded and transcribed and their content was later analysed using the QSR NVivo software. Inductive coding was applied for the data analysis, with no prior categorisation scheme and following the content analysis suggested by Hsieh and Shannon (2005). The analysis started with open coding and line-by-line examination of the transcripts. The various codes were merged into categories and given names. Finally, the various categories were summarised into topics covering how prioritisation is carried out and the various challenges experienced.

To identify the impacted stakeholders and factors, a series of focus groups was held. This is an adaptable approach, which offers tools to develop an understanding of the stakeholder's categories and to reach group consensus (Reed et al., 2009). Krueger and Casey (2014) provide some guidelines for designing and conducting focus groups, based on four features. First, the recruitment of the participants should consider people with knowledge in the area. Second, a comfortable environment should be created, in a setting familiar to the participants. Third, the moderator should be prepared to keep the group engaged. Finally, the discussions should be recorded and the data analysed.

Following the guidelines of Krueger and Casey (2014) for focus groups, the authors aimed for the participation of both academics and practitioners working in fields related to production disturbances. Five focus groups were held. Table 2 presents a brief description of the participants in the various sessions.

The focus group discussion began with a presentation of the background to the research and the objectives of the session. The participants were then asked to consider the various stakeholders which might be affected when a production disturbance happens and write down their answers on paper. They were then asked to share and explain their different answers to the group. Later, the participants were asked to do the same regarding the different factors potentially impacted by production disturbances. Finally, provided with a list of all the impacted factors, the participants were asked to reach a consensus on the more relevant factors for RCA prioritisation of production disturbances. During the whole session, one moderator kept track of the time and encouraged all participants to share their thoughts.

The focus group discussions were recorded and all the paper used by the participants (identifying stakeholders and factors) was collected. Audio records were transcribed and their content analysed. The data written on the pieces of paper were also transcribed and then divided into different categories of stakeholders and impacted factors. The various categories used were pre-defined, taking into account the different levels of the firm adapted and inspired from Kirwan (2000) and Lundgren et al. (2020).

\begin{tabular}{llcl}
\hline Workshop & Type of participants & $\begin{array}{c}\text { Number of } \\
\text { participants }\end{array}$ & Focus area \\
\hline 1 & $\begin{array}{l}\text { Academics } \\
\text { Practitioners from }\end{array}$ & 3 & $\begin{array}{l}\text { Production, maintenance } \\
\text { Production, maintenance, continuous } \\
\text { improvement }\end{array}$ \\
3 & $\begin{array}{l}\text { company B } \\
\text { Practitioners from }\end{array}$ & 5 & $\begin{array}{l}\text { Production, maintenance, continuous } \\
\text { improvement }\end{array}$ \\
4 & $\begin{array}{l}\text { company A } \\
\text { Practitioners from } \\
\text { company C }\end{array}$ & 3 & Production, maintenance \\
5 & $\begin{array}{l}\text { Practitioners from } \\
\text { company D }\end{array}$ & 3 & Production, maintenance, tool maintenance
\end{tabular}

Table 2.

Focus group participants 
To increase the research quality, some additional actions were taken during this work as suggested by Creswell and Miller (2000) and Riege (2003). As much as possible, the authors also collected and analysed internal documents relating to the management of production disturbances, such as minutes of meetings, disturbance records and company reports. The results of this work were also presented to key respondents within the process and their comments incorporated into the work.

\section{Results}

\subsection{Mapping of current situation and challenges}

All the manufacturing companies interviewed for this work use software to record and control their production disturbances. The average number of registered disturbances appears in Table 3 . There is major variation in the frequency of disturbances among the companies; from 40 to 260 per day. The companies have different manufacturing processes, with differing numbers of machines and products and this influences the frequency of disturbances. Despite their different systems, it may be concluded that the frequency of disturbances is high since, even in the company with the lowest frequency (Company D), the average number of production disturbances is still 40/day.

As shown in Table 3, the companies interviewed have diverse prioritisation processes for $\mathrm{RCA}$ of production disturbances. Companies A and B hold regular discussion meetings with the relevant departments; production, maintenance, quality and continuous improvement. The time spent on prioritisation is a challenge in the case of companies $\mathrm{A}$ and $\mathrm{B}$. In those companies, there is a discussion between the various departments until a consensus is reached about what disturbances should be prioritised for RCA, which requires a lot of time.

By contrast, companies $\mathrm{C}$ and $\mathrm{D}$ have an individual, centralised process. In those companies, the production manager decides what disturbances should undergo RCA. Companies $\mathrm{C}$ and $\mathrm{D}$ face a different challenge in their prioritisation process; it becomes person-dependent. In the absence of managers, the process may be blocked.

Regarding the prioritisation criteria, companies A and B have at least one pre-defined criteria each. Company A focuses on the disturbances in the bottleneck machines and their frequency. Company B considers the disturbance duration to set its priority. However, in both companies, different criteria might arise during the regular discussions between the related departments and end up as priorities. For example, if company B is producing an important order, a disturbance related to this order might be considered a priority even if it does not fulfil the pre-defined duration criteria. Using criteria other than the pre-defined ones may make the prioritisation process unclear for the groups working on disturbance management. Consequently, the focus and alignment of the groups may be lost in the process.

In companies $\mathrm{C}$ and $\mathrm{D}$, since the prioritisation is grounded solely in the manager's rationale, the criteria used may be even less clear to the employees. A further challenge identified is that in those companies, only one perspective aimed at production disturbances tends to be addressed, that of the production department.

The use of past data to support the prioritisation process in the companies is very limited. The various disturbance patterns are not factored into the analysis, even though data is available. The companies rely mainly on static analyses, such as Pareto. There is also no formal procedure for capturing knowledge and collecting data for reuse in the actual prioritisation process.

In all companies, the interviewees' perception is that there is room for improvement in the prioritisation process. Greater potential is perceived for companies $\mathrm{C}$ and $\mathrm{D}$ than for $\mathrm{A}$ and $\mathrm{B}$.

In summary, the following challenges were identified among the companies: 
IJQRM

39,5

\begin{tabular}{|c|c|c|c|c|c|}
\hline Company & $\begin{array}{l}\text { Average } \\
\text { number of } \\
\text { registered } \\
\text { disturbances }\end{array}$ & $\begin{array}{l}\text { RCA prioritisation } \\
\text { process }\end{array}$ & Criteria & $\begin{array}{l}\text { Timing of } \\
\text { priority }\end{array}$ & $\begin{array}{l}\text { Perception of } \\
\text { prioritisation }\end{array}$ \\
\hline A & $\sim 70 /$ day & $\begin{array}{l}\text { Weekly meetings to } \\
\text { discuss and } \\
\text { prioritise past } \\
\text { disturbances. } \\
\text { Prioritisation based } \\
\text { on consensus among } \\
\text { people from } \\
\text { different } \\
\text { departments }\end{array}$ & $\begin{array}{l}\text { Focus is on the } \\
\text { bottleneck } \\
\text { machines and } \\
\text { frequency of the } \\
\text { disturbances. Other } \\
\text { criteria may also be } \\
\text { considered during } \\
\text { the discussions }\end{array}$ & $\begin{array}{l}\text { Time to } \\
\text { reach } \\
\text { consensus }\end{array}$ & $\begin{array}{l}\text { Fair, needs } \\
\text { improvement }\end{array}$ \\
\hline B & $\sim 220$ /day & $\begin{array}{l}\text { Daily meetings to } \\
\text { discuss and } \\
\text { prioritise past } \\
\text { disturbances. } \\
\text { Monthly meeting to } \\
\text { discuss the main } \\
\text { focus areas for } \\
\text { improvement. } \\
\text { Prioritisation based } \\
\text { on consensus among } \\
\text { the various } \\
\text { departments }\end{array}$ & $\begin{array}{l}\text { Duration of } \\
\text { disturbance } \\
\text { considered as a } \\
\text { criterion. Other } \\
\text { criteria may also be } \\
\text { considered during } \\
\text { these discussions }\end{array}$ & $\begin{array}{l}\text { Time to } \\
\text { reach } \\
\text { consensus }\end{array}$ & $\begin{array}{l}\text { Good, with } \\
\text { room for } \\
\text { improvement }\end{array}$ \\
\hline $\mathrm{C}$ & 260/day & $\begin{array}{l}\text { Production manager } \\
\text { daily checks the } \\
\text { disturbances and } \\
\text { prioritises those that } \\
\text { should be analysed } \\
\text { further }\end{array}$ & $\begin{array}{l}\text { Based on manager's } \\
\text { experience and } \\
\text { perception. No clear } \\
\text { or defined criteria }\end{array}$ & $\begin{array}{l}\text { Usually fast, } \\
\text { but } \\
\text { dependent } \\
\text { on the } \\
\text { manager }\end{array}$ & Not so good \\
\hline D & $\sim 40 /$ day & $\begin{array}{l}\text { Daily notification } \\
\text { email sent to all line } \\
\text { supervisors and } \\
\text { managers, listing } \\
\text { past disturbances. } \\
\text { Production manager } \\
\text { prioritises those that } \\
\text { should be further } \\
\text { analysed }\end{array}$ & $\begin{array}{l}\text { Based on manager's } \\
\text { experience and } \\
\text { perception. No clear } \\
\text { or defined criteria }\end{array}$ & $\begin{array}{l}\text { Usually fast, } \\
\text { but depends } \\
\text { on the } \\
\text { manager }\end{array}$ & Not so good \\
\hline
\end{tabular}

Table 3.

RCA prioritisation in the companies

\section{0}

(1) When the group makes the decision, time is needed to reach a consensus;

(2) When prioritisation is centralised in one person, the process becomes persondependent;

(3) When prioritisation is centralised in one person, priorities are usually set based solely on the production perspective;

(4) The criteria for setting priorities may be unclear;

(5) There is limited use of data to support prioritisation decision-making. 


\subsection{Impacted stakeholders and impacted factors}

After conducting interviews with the companies, the authors conducted a series of focus groups with academics and practitioners. The objective was to identify all possible stakeholders and factors impacted when a production disturbance happens. The authors' rationale was that these should be considered when priorities are being set. Table 4 shows the stakeholders identified by the focus groups.

Operators, managers, customers and the sales/marketing, maintenance, planning and production departments were cited by all focus groups as stakeholders affected by production disturbances. Other departments impacted are logistics, quality, safety, finance, purchase and human resources. The chief executive officer (CEO), owners and shareholders were also identified as stakeholders. Within the companies, almost all functions may be impacted. The effects of production disturbances are not restricted to the production and maintenance domain. Other stakeholders include suppliers, equipment manufacturers, authorities, society, employees' families, industrial organisations, competitors, academics and even the environment.

The identified stakeholders were classified into four levels: (1) individual, (2) plant, (3) firm and (4) outside the firm, as shown in Figure 2. Disturbances may impact many different roles. People working directly with the disturbances might immediately feel their consequences, such as operators, managers and consultants. Depending on the disturbances, the effects may even reach the employees' families.

At the plant level, a great variety of departments may be impacted. The effects of the production disturbances encroach on the production and maintenance departments. Among
Production disturbance prioritisation

\begin{tabular}{|c|c|c|c|c|c|c|}
\hline & Academics & Company A & Company B & Company C & Company D & \\
\hline Operators & $\mathrm{X}$ & $\mathrm{X}$ & $\mathrm{X}$ & $\mathrm{X}$ & $\mathrm{X}$ & \\
\hline Managers & $\mathrm{X}$ & $\mathrm{X}$ & $\mathrm{X}$ & $\mathrm{X}$ & $\mathrm{X}$ & \\
\hline Customers & $\mathrm{x}$ & $\mathrm{X}$ & $\mathrm{X}$ & $\mathrm{X}$ & $\mathrm{X}$ & \\
\hline Sales/marketing department & $\mathrm{X}$ & $\mathrm{X}$ & $\mathrm{X}$ & $\mathrm{X}$ & $\mathrm{X}$ & \\
\hline Maintenance department & $\mathrm{X}$ & $\mathrm{X}$ & $\mathrm{X}$ & $\mathrm{X}$ & $\mathrm{X}$ & \\
\hline Planning department & $\mathrm{X}$ & $\mathrm{X}$ & $\mathrm{X}$ & $\mathrm{X}$ & $\mathrm{X}$ & \\
\hline Production department & $\mathrm{X}$ & $\mathrm{X}$ & $\mathrm{X}$ & $\mathrm{X}$ & $\mathrm{X}$ & \\
\hline Logistics department & $\mathrm{X}$ & & $\mathrm{X}$ & & $\mathrm{X}$ & \\
\hline Quality department & $\mathrm{X}$ & & $\mathrm{X}$ & & $\mathrm{X}$ & \\
\hline Safety department & $\mathrm{X}$ & $\mathrm{X}$ & & & & \\
\hline Finance department & $\mathrm{X}$ & & & & & \\
\hline Human resources department & & & $\mathrm{X}$ & & & \\
\hline Purchasing department & & & $\mathrm{X}$ & & & \\
\hline Tool department & & & & & $\mathrm{X}$ & \\
\hline Owners & $\mathrm{X}$ & $\mathrm{X}$ & $\mathrm{X}$ & & & \\
\hline Shareholders & $\mathrm{X}$ & & & & & \\
\hline CEO & $\mathrm{X}$ & & & & & \\
\hline Suppliers & $\mathrm{X}$ & $\mathrm{X}$ & & $\mathrm{X}$ & & \\
\hline Equipment manufacturers & $\mathrm{X}$ & $\mathrm{X}$ & & & & \\
\hline Authorities & $\mathrm{X}$ & $\mathrm{X}$ & & & & \\
\hline Society & $\mathrm{X}$ & $\mathrm{X}$ & & & & \\
\hline Industrial organisations & $\mathrm{X}$ & & & & & \\
\hline Competitors & $\mathrm{X}$ & & & & & \\
\hline Consultants & $\mathrm{X}$ & & & & & \\
\hline Employees' families & $\mathrm{X}$ & & & & & Table 4. \\
\hline Environment & $\mathrm{X}$ & & & & & Identified impacted \\
\hline Academics & $\mathrm{X}$ & & & & & stakeholders \\
\hline
\end{tabular}


IJQRM

39,5

1142

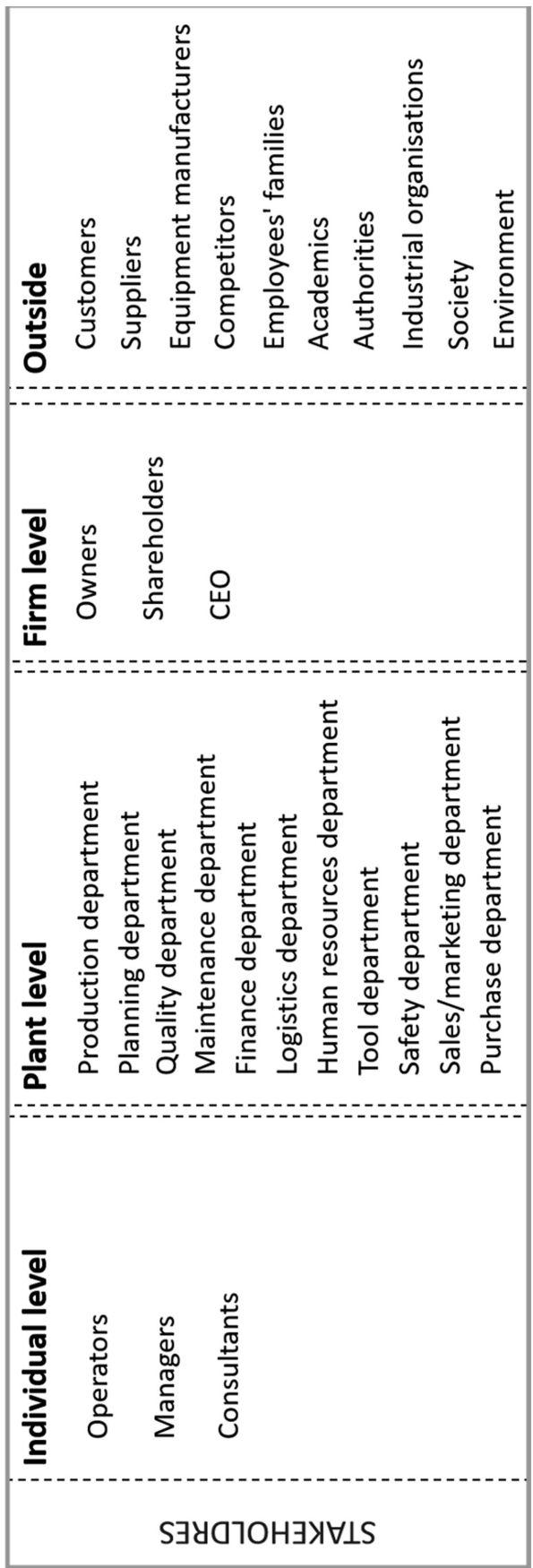


others, quality, planning, logistics, safety and even the finance and human resources departments may be involved (see Figure 2). Depending on the disturbance, almost all employees within an organisation may feel the impacts.

Outside the firm, customers are unlikely to be the only ones suffering the consequences of disturbances; suppliers and equipment manufacturers may do too. The entire supply chain may be impacted when a production disturbance takes place. Context-setters such as authorities and industrial organisations may also be affected, especially in case of catastrophic disturbances, occasioning a need for new regulations. The environment is also impacted. Competitors are probably the only stakeholder who might be positively affected by the occurrence of production disturbances. However, in the long term and overall, disturbances create mainly negative impacts on society.

In prioritising RCA of production disturbances, the number of stakeholders to consider is extensive. The task of trying to balance and meet the various needs may be quite challenging to the managers or groups that must set the priorities.

In the second part of the focus group discussions, the authors identified the factors impacted by disturbances. Table 5 shows these factors, plus those considered more relevant (marked - ). Production disturbances affect a wide range of factors. In the focus groups, a total of 46 factors were identified. Of those, 14 were defined as most relevant: quality, work environment, safety, time, results, customer satisfaction, productivity, deliverability, resource utilisation, profit, process flow, plannability, machine health and reputation.

The authors divided the impacted factors into different levels in the firm (see Figure 3), similar to what was done with the impacted stakeholders. At each of the levels, the impacted factors were also classified according to the different business objectives. The factors considered most critical appear in bold.

Production disturbances affect factors at the company level and beyond. Outside the company, customers' interests are associated with satisfaction, deliverability and trust in the company. A company's reputation also affects the relationship to other external stakeholders, such as suppliers, equipment manufacturers, industrial organisations, authorities and society. Production disturbances may impact business relationships with those stakeholders and even lead to legal consequences.

At the plant level, production disturbances may impact nearly all business objectives and dimensions of performance: manufacturing, maintenance, environmental and safety. Production disturbances are closely related to quality problems in end products, time spent on production and production capacity. Furthermore, the more disturbances a system is subjected to, the harder it is to plan operations and predict the behaviour of a production system. The operation's complexity becomes greater, affecting logistics and causing constant re-planning of production. Strategies such as raising stock levels are common ways of dealing with the production variability caused by disturbances.

Moreover, disturbances impact machine health, as they create turbulence and make it impossible for machines to operate under ideal, stable conditions. Maintenance budgets may have to increase due to the diminished availability and reliability caused by unpredictable production disturbances.

Disturbances also affect resource use. The more disturbances a system is subjected to, the more waste is generated as more resources are used to achieve the same production rate. More energy is also used, thereby impacting environmental sustainability.

Production disturbances also compromise safety. With less predictable processes, people working in production systems may encounter new, unfamiliar circumstances which they cannot handle. For companies with safety-critical production systems, this situation is worsened. A disturbance may initiate an accident, due to employees being exposed to unstable conditions.
Production disturbance prioritisation

1143 
IJQRM

39,5

1144
The individual level is impacted but not just because production disturbances diminish safety. They also cause the work environment to be less attractive. A higher workload is created for operators and managers because of the need to continuously solve unexpected problems. This may lead to more stress, affecting employees' motivation, engagement and even their personal lives. In an unpredictable environment, employees' energies are directed at fire-fighting production disturbances.

\begin{tabular}{|c|c|c|c|c|c|}
\hline Impacted factor & Academics & Company A & Company B & Company C & Company D \\
\hline Quality & $\mathrm{X}$ & ? & - & 0 & - \\
\hline Work environment & $\mathrm{X}$ & $\mathrm{X}$ & - & - & - \\
\hline Safety & - & - & & 0 & \\
\hline Time & $\mathrm{X}$ & $\mathrm{X}$ & $\mathrm{X}$ & 0 & 0 \\
\hline Results & $\mathrm{X}$ & - & - & $\mathrm{X}$ & $\mathrm{X}$ \\
\hline Customer satisfaction & - & 0 & $\mathrm{X}$ & & \\
\hline Productivity & $\mathrm{X}$ & $\mathrm{X}$ & $\mathrm{X}$ & - & \\
\hline Deliverability & $\mathrm{X}$ & $\mathrm{X}$ & - & & $\mathrm{X}$ \\
\hline Resource utilisation & 0 & $\mathrm{X}$ & & $\mathrm{X}$ & \\
\hline Profit & - & & $\mathrm{X}$ & & \\
\hline Process flow & $\mathrm{X}$ & - & & & - \\
\hline Plannability & & & 0 & & $\mathrm{X}$ \\
\hline Machine health & $\mathrm{X}$ & & & & - \\
\hline Reputation & - & & $\mathrm{X}$ & & \\
\hline Cost & $\mathrm{X}$ & $\mathrm{X}$ & $\mathrm{X}$ & $\mathrm{X}$ & $\mathrm{X}$ \\
\hline Employee stress & $\mathrm{X}$ & & $\mathrm{X}$ & & $\mathrm{X}$ \\
\hline Employee wellbeing & $\mathrm{X}$ & & $\mathrm{X}$ & & \\
\hline Working hours & $\mathrm{X}$ & & $\mathrm{X}$ & & \\
\hline Engagement & & & & $\mathrm{X}$ & $\mathrm{X}$ \\
\hline Waste generation & $\mathrm{X}$ & & $\mathrm{X}$ & & \\
\hline Effectivity & & & $\mathrm{X}$ & $\mathrm{X}$ & \\
\hline
\end{tabular}

Table 5.

Identified impacted factors
Energy consumption

Equipment utilisation

Legal consequences

Maintainability

Operations' complexity

People turnover

Physical ergonomics

Psychological ergonomics

Reliability

Stock level

Sustainability

Availability

Logistics

Investment need

Predictability

Business relationships

Re-planning

Strategic activities

Delays

Backlog activities

Workload

Maintenance budget

Customer trust

Motivation

Employees' private lives
$\mathrm{X}$

$\mathrm{X}$

$\mathrm{X}$

$\mathrm{X}$

$\mathrm{X}$

$\mathrm{X}$

$\mathrm{X}$

$\mathrm{X}$

X

X

X

X

$\mathrm{X}$
$\mathrm{X}$
$\mathrm{X}$

$X$
$X$
$X$
$X$
$X$
$X$
$X$

X 


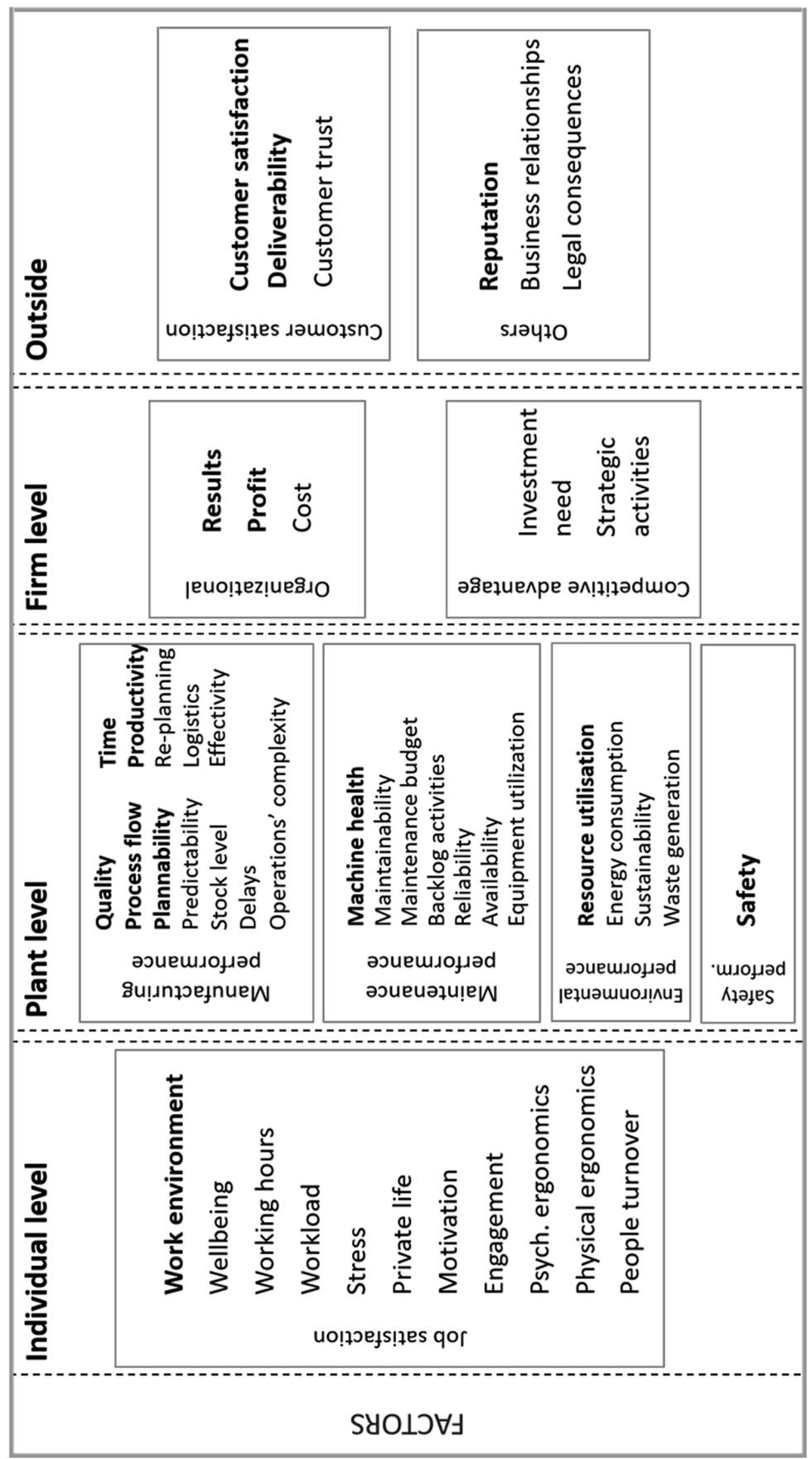

Production disturbance prioritisation

Figure 3. Levels and impacted factors 
IJQRM

39,5

In summary, at the firm level, company results are affected. Disturbances cause higher production costs and lower profits. More investment may be needed to fix, correct and remedy disturbances, all of which affect a firm's strategic decisions.

\section{Discussion}

In this work, the authors investigated the current situation of RCA prioritisation of production disturbances and the challenges faced by manufacturing companies. The various stakeholders and factors affected by disturbances were also identified.

Various works have examined the current situation regarding the management of production disturbances, such as Bokrantz et al. (2016) and Islam and Tedford, (2012). To complement the available literature, this work also presented the current situation regarding RCA prioritisation of production disturbances. Different types of challenges are currently faced by companies in this area. Among companies that have a group of people from different departments to make the decision, the time spent to reach a consensus tends to be high. In the case of companies where the production manager is the one doing the prioritisation, the process tends to be person-dependent and to only consider the production department's perspective. In all companies, the use of data for the decision is very limited and priorities are normally set based on unclear criteria.

The RCA investigation demands time and resources (Andersen and Fagerhaug, 2002; Mahto and Kumar, 2008). In this work, the authors identified that the RCA prioritisation may also be time-consuming, particularly when a group is making the decision. The right strategy may help companies save time at the prioritisation stage and focus their efforts on investigating the root causes of disturbances. RCA is a necessary step in the proactive management of production disturbances. It is critical to prioritise which disturbances will undergo RCA, so that greater benefits to the production system may be achieved.

When it comes to identifying stakeholders, the results indicate that production disturbances affect a wide range of roles. Almost all departments within the companies are impacted and the effects may even be felt beyond the companies. When prioritising, managers and groups working with disturbances may take the identified stakeholders and impacts into consideration. Factoring stakeholders into decision-making increases a company's chances of business success (Reed et al., 2009). No previous literature has systematically identified the stakeholders impacted by production disturbances.

When reducing the frequency of production disturbances, companies may increase their OEE and use their production capacities more efficiently (Ylipää et al., 2017). However, the benefits of reducing production disturbances are not limited to increasing OEE. The results indicate that many other aspects are also impacted by production disturbances, the most relevant being quality, work environment, safety, time, company results, customer satisfaction, productivity, deliverability, resource utilisation, profit, process flow, plannability, machine health and reputation. Those factors should also be considered during the prioritisation process, to maximise value creation in the production system.

Even though this work has focused on identifying the impacted stakeholders and factors involved in RCA prioritisation of production disturbances, the results also apply to the other stages of production disturbance management. For example, when conducting a risk evaluation, practitioners may take into consideration who and what is impacted. One shortcoming of FMEA is the difficulty of evaluating the risk factors precisely (Liu et al., 2013). Concerning the severity criteria used in FMEA, identifying stakeholders and factors may result in a better assessment. Other stages which may benefit from considering stakeholders and factors include those in which some type of prioritisation might be needed, such as detection and correction/mitigation. 
The contributions of this work are twofold. First, it augments the mapping of how manufacturing companies currently manage production disturbances by highlighting the current challenges regarding RCA prioritisation. The understanding of current challenges and the identification of the stakeholders and the factors impacted by disturbances are necessary knowledge if companies are to develop more efficient RCA prioritisation strategies.

The challenges presented in this work may help direct academics to those areas in which practitioners lack support regarding RCA prioritisation. Then, academics can focus in helping practitioners to seek solutions to overcome the identified challenges.

The identified impacted stakeholders and factors may be used in the RCA prioritisation decision-making process. Once a disturbance happens, practitioners may use the identified stakeholders and factors to support their analysis of the impacts of the disturbance and, consequently, the need for prioritisation.

There are various suggestions for future work. First, the authors suggest the verification of the relationships between different stakeholders and factors. Although the stakeholders and factors were identified in this work, the authors did not establish their relationships. For example, a disturbance might impact productivity, which may lead to an effect on the company's results. The same might happen among the stakeholders, in that one stakeholder is impacted, leading to a consequence for another one. One possible approach to establish the relationship among the identified stakeholders and factors is the use of the interpretive structural modelling as described by Attri et al. (2013).

Additionally, the identified stakeholders have different levels of power and interest when it comes to production disturbance management. This may also affect the prioritisation process and may depend on a company's circumstances and setting. Further investigation of this kind is also needed.

Furthermore, the authors would also propose developing an automatic RCA prioritisation tool. The identified challenges, stakeholders and factors should be considered as designing inputs for such a tool. Once designed, it may be implemented to test whether the intended outcomes are achieved.

\section{Conclusions}

The objective of this research was to investigate RCA prioritisation of production disturbances. The authors studied the current situation among manufacturing companies using a series of interviews. Additionally, the stakeholders and factors impacted by production disturbances were identified in a series of workshops involving practitioners and academics working in the area.

Manufacturing companies face challenges in prioritising which production disturbances should undergo root cause analysis. If a group is undertaking the prioritisation, a challenge was identified relating to the time needed to reach a consensus. If prioritisation centres on a manager, the challenge is that the process becomes person-dependent, solely reflecting the perspective of the production department. Additionally, unclear criteria are commonly used to set priorities and very limited data is used to support decision-making.

In setting priorities, it is critical to know who the different stakeholders are and how they may be affected. For this reason, this research identified the impacted stakeholders and factors using the occurrence of production disturbances. A wide range of stakeholders and factors are impacted, reaching beyond the walls of companies and affecting customers, suppliers and the environment, among other things. The most relevant impacted factors affected quality, work environment, safety, time, results, customer satisfaction, productivity, deliverability, resource utilisation, profit, process flow, plannability, machine health and reputation.
Production disturbance prioritisation

1147 
IJQRM

39,5

With an understanding of the current situation and the various impacted factors and stakeholders, solutions for effective RCA prioritisation may be proposed. Better RCA prioritisation may lead to a reduction in the frequency and duration of disturbances. This is necessary to establish more resilient production systems.

\section{References}

Abellana, D.P. (2020), "A proposed hybrid root cause analysis technique for quality management”, International Journal of Quality and Reliability Management, Vol. 38 No. 3, pp. 704-721, doi: 10.1108/IJQRM-11-2019-0356.

Aguinis, H. and Solarino, A.M. (2019), "Transparency and replicability in qualitative research: the case of interviews with elite informants", Strategic Management Journal, Vol. 40 No. 8, pp. 1291-1315, doi: 10.1002/smj.3015.

Alsyouf, I. (2007), “The role of maintenance in improving companies' productivity and profitability", International Journal of Production Economics, Vol. 105 No. 1, pp. 70-78, doi: 10.1016/j.ijpe.2004. 06.057 .

Andersen, B. and Fagerhaug, T. (2002), "Root cause analysis: simplified tools and techniques", Journal for Healthcare Quality, Vol. 24 No. 3, pp. 46-47, doi: 10.1097/01445442-200205000-00012.

Attri, R., Dev, N. and Sharma, V. (2013), "Interpretive structural modelling (ISM) approach: an overview”, Research Journal of Management Sciences, Vol. 2319 No. 2, p. 1171.

Bokrantz, J., Skoogh, A., Ylipää, T. and Stahre, J. (2016), "Handling of production disturbances in the manufacturing industry", Journal of Manufacturing Technology Management, Vol. 27 No. 8, pp. 1054-1075, doi: 10.1108/JMTM-02-2016-0023.

Chong, A.K.W., Mohammed, A.H., Abdullah, M.N. and Rahman, M.S.A. (2019), "Maintenance prioritization - a review on factors and methods", Journal of Facilities Management, Vol. 17 No. 1, pp. 18-39, doi: 10.1108/JFM-11-2017-0058.

Creswell, J.W. and Miller, D.L. (2000), "Determining validity in qualitative inquiry", Theory into Practice, Vol. 39 No. 3, pp. 124-130, doi: 10.1207/s15430421tip3903_2.

Dorsch, J.J., Yasin, M.M. and Czuchry, A.J. (1997), "Application of root cause analysis in a service delivery operational environment: a framework for implementation”, International Journal of Service Industry Management, Vol. 8 No. 4, pp. 268-289, doi: 10.1108/ 09564239710174372.

Edmondson, A.C. and Mcmanus, S.E. (2007), "Methodological fit in management field research", Academy of Management Review, Vol. 32 No. 4, pp. 1155-1179, doi: 10.5465/AMR.2007. 26586086.

Gopalakrishnan, M. and Skoogh, A. (2018), "Machine criticality based maintenance prioritization: identifying productivity improvement potential", International Journal of Productivity and Performance Management, Vol. 67 No. 4, pp. 654-672, doi: 10.1108/ IJPPM-07-2017-0168.

Hillman, A.J. and Keim, G.D. (2001), "Shareholder value, stakeholder management, and social issues: what's the bottom line?", Strategic Management Journal, Vol. 22 No. 2, pp. 125-139, doi: 10.1002/ 1097-0266(200101)22:2<125::AID-SMJ150>3.0.CO;2-H.

Hsieh, H.F. and Shannon, S.E. (2005), "Three approaches to qualitative content analysis”, Qualitative Health Research, Vol. 15 No. 9, pp. 1277-1288, doi: 10.1177/1049732305276687.

Ingemansson, A. (2004), On Reduction of Production Disturbances in Manufacturing Systems Based on Discrete-Event Simulation, Lund Institute of Technology, Lund.

Islam, A. and Tedford, D. (2014), "Risk determinants of small and medium-sized manufacturing enterprises (SMEs) - an exploratory study in New Zealand", Journal of Industrial Engineering International, Vol. 8 No. 1, doi: 10.1186/2251-712X-8-12. 
Kallio, H., Pietilä, A.M., Johnson, M. and Kangasniemi, M. (2016), "Systematic methodological review: developing a framework for a qualitative semi-structured interview guide", Journal of Advanced Nursing, Vol. 72 No. 12, pp. 2954-2965, doi: 10.1111/jan.13031.

Kirwan, B. (2000), "Soft systems, hard lessons”, Applied Ergonomics, Vol. 31 No. 6, pp. 663-678, doi: 10. 1016/S0003-6870(00)00041-7.

Knights, P.F. (2001), "Rethinking Pareto analysis: maintenance applications of logarithmic scatterplots", Journal of Quality in Maintenance Engineering, Vol. 7 No. 4, pp. 252-263, doi: 10.1108/13552510110407041.

Krueger, R.A. and Casey, M.A. (2014), Focus Groups: A Practical Guide for Applied Research, 5th ed., SAGE Publications, available at: https://books.google.se/books?id=ai7goAEACAAJ.

Leitao, P. and Francisco, R. (2004), "Predictive disturbance management in manufacturing control systems", Vol. 671, pp. 164-167, available at: https://bibliotecadigital.ipb.pt/bitstream/10198/ 1546/1/2004-IMSForum.pdf.

Liu, H.C., Liu, L. and Liu, N. (2013), "Risk evaluation approaches in failure mode and effects analysis: a literature review", Expert Systems with Applications, Vol. 40 No. 2, pp. 828-838, doi: 10.1016/j. eswa.2012.08.010.

Lundgren, C., Bokrantz, J. and Skoogh, A. (2020), "Performance indicators for measuring the effects of Smart Maintenance", International Journal of Productivity and Performance Management, Vol. ahead-of-print No. ahead-of-print, doi: 10.1108/IJPPM-03-2019-0129.

Mahto, D. and Kumar, A. (2008), "Application of root cause analysis in improvement of product quality and productivity”, Journal of Industrial Engineering and Management, Vol. 1 No. 2, pp. 16-53, doi: 10.3926/jiem.2008.v1n2.p16-53.

Murugaiah, U., Benjamin, S.J., Marathamuthu, M.S. and Muthaiyah, S. (2010), "Scrap loss reduction using the 5-whys analysis", International Journal of Quality and Reliability Management, Vol. 27 No. 5, pp. 527-540, doi: 10.1108/02656711011043517.

Nieto-Rodriguez, A. (2016), "How to prioritize your company's projects", Harvard Business Review Digital Articles, December 2016, pp. 2-5, available at: https://hbr.org/2016/12/how-to-prioritizeyour-companys-projects.

Puente, J., Pino, R., Priore, P. and de la Fuente, D. (2002), “A decision support system for applying failure mode and effects analysis", International Journal of Quality and Reliability Management, Vol. 19 No. 2, pp. 137-150, doi: 10.1108/02656710210413480.

Reed, M.S., Graves, A., Dandy, N., Posthumus, H., Hubacek, K., Morris, J., Prell, C., Quinn, C.H. and Stringer, L.C. (2009), "Who's in and why? A typology of stakeholder analysis methods for natural resource management", Journal of Environmental Management, Vol. 90 No. 5, pp. 1933-1949, doi: 10.1016/j.jenvman.2009.01.001.

Reid, I. and Smyth-Renshaw, J. (2012), "Exploring the fundamentals of root cause analysis: are we asking the right questions in defining the problem?", Quality and Reliability Engineering International, Vol. 28 No. 5, pp. 535-545, doi: 10.1002/qre.1435.

Riege, A.M. (2003), "Validity and reliability tests in case study research: a literature review with "hands-on" applications for each research phase", Qualitative Market Research: An International Journal, Vol. 6 No. 2, pp. 75-86, doi: 10.1108/13522750310470055.

Sankar, N.R. and Prabhu, B.S. (2006), "Modified approach for prioritization of failures in a system failure mode and effects analysis", International Journal of Quality and Reliability Management, Vol. 18 No. 3, pp. 324-335.

Stokes, D. and Bergin, R. (2006), "Methodology or "methodolatry"? An evaluation of focus groups and depth interviews", Qualitative Market Research, Vol. 9 No. 1, pp. 26-37, doi: 10.1108/ 13522750610640530 .

Stricker, N. and Lanza, G. (2014), "The concept of robustness in production systems and its correlation to disturbances", Procedia CIRP, Vol. 19, pp. 87-92, doi: 10.1016/j.procir.2014.04.078. 
IJQRM

39,5

1150

Voss, C., Tsikriktsis, N. and Frohlich, M. (2002), "Case research in operations management", International Journal of Operations and Production Management, Vol. 22 No. 2, doi: 10.1108/ 01443570210414329.

Watkins, M.D. and Bazerman, M.H. (2003), "Predictable surprises: the disasters you should have seen coming", Harvard Business Review, Vol. 81 No. 3.

Westbrook, R. (1994), "Priority management: new theory for operations management", International Journal of Operations and Production Management, Vol. 14 No. 6, pp. 4-24, doi: 10.1108/01443579410062059.

Ylipää, T. (2000), High-Reliability Manufacturing Systems, Chalmers University of Technology, Gothenburg.

Ylipää, T., Skoogh, A., Bokrantz, J. and Gopalakrishnan, M. (2017), "Identification of maintenance improvement potential using OEE assessment", International Journal of Productivity and Performance Management, Vol. 66 No. 1, pp. 126-143, doi: 10.1108/IJPPM-01-2016-0028.

\section{Corresponding author}

Adriana Soares Ito can be contacted at: adriana.ito@chalmers.se

For instructions on how to order reprints of this article, please visit our website:

www.emeraldgrouppublishing.com/licensing/reprints.htm

Or contact us for further details: permissions@emeraldinsight.com 